Journal of Extension Education

Vol. 29 No. 4, 2017

DOI:https: / /doi.org/10.26725/JEE.2017.4.29.5988-5994

\title{
Sustainability of Participatory Technology Development \& Transfer Approach for Sugarcane Farmers
}

\author{
J.Vasanthakumar ${ }^{1}$
}

\begin{abstract}
Participatory Technology Development and Transfer (PTD \& T) is an effective action research approach. It empowers all the stakeholders, especially the farmers who are many a time invisible. A PTD project was implemented for Sugarcane development in Tamil Nadu and the outcome was a mixture of success and failures. The paper presents the findings and asserts that the approach is sustainable.
\end{abstract}

Keywords: Participatory Technology Development and Transfer; Transect Walk ; Sugarcane; Constraints; Tamil Nadu

Generally scientists develop high input technologies in research centres and development workers transfer the technologies to farmers. The approach worked well in many of the regions with sufficient resources. However, the technologies were not utilised in some of the regions operating under physical and socio-economic constraints (Garforth and Harford, 1995). It is mainly due to the fact that real needs of the farmers of such regions were not reflected in the whole process of Technology Generation and Transfer' (Pretty, 1995).

\section{METHODOLOGY}

The study was taken up in three villages of Nagappattinam district in Tamil Nadu under the jurisdiction of
N.P.K.R.R Cooperative Sugar Mills Ltd., based on yield gap. The yield gap was operationally defined as the ratio between potential high yield recorded in the village and average yield of the village (Dhamodaran and Vasanthakumar, 1997). Three villages namely, Athukkudi, Keelaiyur and Thiruvali were selected based on high yield gaps.

\section{FINDINGS AND DISCUSSION}

Transect walk and analysis

Scientists from ICAR-Sugarcane Breeding Institute, Coimbatore and Development workers of N.P.K.R.R Sugar Mills, Mayiladuthurai and Faculty of Agriculture, Annamalai University along with farmers of each village selected

1. Former Dean (Agriculture), Annamalai University, Chidambaram, Tamil Nadu

Received : 02-08-2018; Accepted : 16-08-2018 
Table 1.

Problems Presented by Farmers in Athukkudi village of Nagappattinam district

$(\mathrm{n}=27)$

\begin{tabular}{|c|c|c|c|c|c|}
\hline $\begin{array}{l}\text { S1. } \\
\text { No. }\end{array}$ & Problem & $\begin{array}{l}\text { S1. } \\
\text { No. }\end{array}$ & Problem & $\begin{array}{l}\text { S1. } \\
\text { No. }\end{array}$ & Problem \\
\hline 1 & $\begin{array}{l}\text { Lack of suitable } \\
\text { varieties for brief } \\
\text { drought condition }\end{array}$ & 2 & $\begin{array}{l}\text { Improper land } \\
\text { preparation }\end{array}$ & 3 & $\begin{array}{l}\text { Inappropriate } \\
\text { water management } \\
\text { practices }\end{array}$ \\
\hline 4 & $\begin{array}{l}\text { Non-adoption } \\
\text { of drought } \\
\text { management } \\
\text { technologies }\end{array}$ & 5 & $\begin{array}{l}\text { Late planting of } \\
\text { sugarcane }\end{array}$ & 6 & $\begin{array}{l}\text { Water logging } \\
\text { during October- } \\
\text { November }\end{array}$ \\
\hline 7 & $\begin{array}{l}\text { Incidence of Early } \\
\text { Shoot borer }\end{array}$ & 8 & $\begin{array}{l}\text { Heavy weed } \\
\text { infestation }\end{array}$ & 9 & Soil problems \\
\hline 10 & Rat problems & 11 & $\begin{array}{l}\text { Internode borer } \\
\text { problem }\end{array}$ & 12 & Top borer problem \\
\hline 13 & Red rot disease & 14 & Smut disease & 15 & Poor germination \\
\hline 16 & $\begin{array}{l}\text { Inappropriate } \\
\text { fertiliser } \\
\text { management }\end{array}$ & 17 & $\begin{array}{l}\text { Lack of soil test } \\
\text { details }\end{array}$ & 18 & $\begin{array}{l}\text { Lack of Water test } \\
\text { details }\end{array}$ \\
\hline 19 & $\begin{array}{l}\text { Harvesting not done } \\
\text { at ground level }\end{array}$ & 20 & $\begin{array}{l}\text { Detrashing not } \\
\text { done }\end{array}$ & 21 & $\begin{array}{l}\text { Poor Ratoon } \\
\text { management }\end{array}$ \\
\hline 22 & $\begin{array}{l}\text { Low level of use of } \\
\text { organic manure }\end{array}$ & 23 & Termite problem & 24 & Whitefly problem \\
\hline 25 & $\begin{array}{l}\text { Varietal mixture } \\
\text { especially during } \\
\text { gap- filling }\end{array}$ & & & & \\
\hline
\end{tabular}

undertook the transect walk initially and then assembled at a common place for a presentation of problems by farmers. Problems in Sugarcane production were presented by farmers after a Transect
Walk in the three villages. The Scientists listened carefully to the presentation of problems made by farmers (Arulraj and Vasanthakumar. 1996). 
There were twenty-five problems listed by the farmers of Athukkudi village (Table1). The facilitators of the project facilitated a discussion among all the stakeholders and listed the priorities of the farmers of Athukkudi village. The problems that required immediate attention were identified: (i) Selection of Sugarcane varieties suitable to brief drought condition, (ii) Methods of Land Preparation, (iii) Water Management, (iv) Management of Early Shoot Borer and (v) Use of Organic Manure.

The farmers of Thiruvali village identified twenty-four problems (Table 2) in the presence of scientists and development workers.

Table 2.

Problems Presented by Farmers in Thiruvali village of Nagappattinam District

$(\mathrm{n}=27)$

\begin{tabular}{|c|c|c|c|c|c|}
\hline $\begin{array}{l}\text { S1. } \\
\text { No. }\end{array}$ & Problem & $\begin{array}{l}\text { S1. } \\
\text { No. }\end{array}$ & Thiruvali & $\begin{array}{l}\text { S1. } \\
\text { No. }\end{array}$ & Keelaiyur \\
\hline 1 & $\begin{array}{l}\text { Poor level of ratoon } \\
\text { management }\end{array}$ & 2 & $\begin{array}{l}\text { Soil problems due } \\
\text { to sandy texture } \\
\text { and Improper land } \\
\text { preparation }\end{array}$ & 3 & $\begin{array}{l}\text { Non-adoption of basal } \\
\text { dose of fertiliser }\end{array}$ \\
\hline 4 & $\begin{array}{l}\text { Heavy incidence of } \\
\text { Early Shoot borer }\end{array}$ & 5 & $\begin{array}{l}\text { Repeated occurrence } \\
\text { of water scarcity }\end{array}$ & 6 & $\begin{array}{l}\text { Late planting of } \\
\text { sugarcane }\end{array}$ \\
\hline 7 & $\begin{array}{l}\text { Inappropriate } \\
\text { sugarcane varieties } \\
\text { cultivated in the } \\
\text { village }\end{array}$ & 8 & $\begin{array}{l}\text { High incidence } \\
\text { of internode borer } \\
\text { problem }\end{array}$ & 9 & $\begin{array}{l}\text { Improper weed } \\
\text { management }\end{array}$ \\
\hline 10 & $\begin{array}{l}\text { High incidence of } \\
\text { termites }\end{array}$ & 11 & Rat menace & 12 & $\begin{array}{l}\text { Profusely flowering } \\
\text { nature of existing } \\
\text { varieties }\end{array}$ \\
\hline 13 & Heavy lodging & 14 & $\begin{array}{l}\text { Non-adoption of } \\
\text { harvesting at ground } \\
\text { level }\end{array}$ & 15 & $\begin{array}{l}\text { Lack of availability } \\
\text { of organic manure in } \\
\text { sufficient quantities }\end{array}$ \\
\hline 16 & $\begin{array}{l}\text { Lack of adoption } \\
\text { of appropriate } \\
\text { fertiliser management } \\
\text { techniques }\end{array}$ & 17 & $\begin{array}{l}\text { Less adoption of soil } \\
\text { testing }\end{array}$ & 18 & $\begin{array}{l}\text { Incidence of red rot } \\
\text { disease in few plots }\end{array}$ \\
\hline
\end{tabular}




\begin{tabular}{|c|l|c|l|c|l|}
\hline $\begin{array}{r}\text { S1. } \\
\text { No. }\end{array}$ & \multicolumn{1}{|c|}{ Problem } & $\begin{array}{r}\text { S1. } \\
\text { No. }\end{array}$ & \multicolumn{1}{|c|}{ Thiruvali } & $\begin{array}{c}\text { S1. } \\
\text { No. }\end{array}$ & \multicolumn{1}{|c|}{ Keelaiyur } \\
\hline 19 & Whitefly problem & 20 & $\begin{array}{l}\text { Improper water } \\
\text { management } \\
\text { practices }\end{array}$ & 21 & $\begin{array}{l}\text { Low level of } \\
\text { germination }\end{array}$ \\
\hline 22 & $\begin{array}{l}\text { Non-availability of } \\
\text { good nursery plots }\end{array}$ & 23 & $\begin{array}{l}\text { Less adoption of half } \\
\text { earthing-up }\end{array}$ & 24 & $\begin{array}{l}\text { Less adoption of deep } \\
\text { ploughing }\end{array}$ \\
\hline
\end{tabular}

The problems that required immediate attention in Thiruvali were identified: (i) Selection of Sugarcane varieties suitable to wetland condition, (ii) Sandy soil Management, and (iii) Ratoon Management.
The farmers of Keelaiyur village had listed out eighteen problems (Table 3). The facilitators discussed the problems for a better understanding.

The problems that required immediate attention in Keelaiyur were

Table 3.

Problems Presented by Farmers in Keelaiyur village of Nagappattinam District $(n=19)$

\begin{tabular}{|c|c|c|c|c|c|}
\hline $\begin{array}{l}\text { S1. } \\
\text { No. }\end{array}$ & Problem & $\begin{array}{l}\text { S1. } \\
\text { No }\end{array}$ & Problem & $\begin{array}{l}\text { S1. } \\
\text { No. }\end{array}$ & Problem \\
\hline 1 & $\begin{array}{l}\text { Non-availability of } \\
\text { suitable varieties for } \\
\text { upland condition }\end{array}$ & 2 & Weed management & 3 & $\begin{array}{l}\text { Poor Ratoon } \\
\text { management }\end{array}$ \\
\hline 4 & $\begin{array}{l}\text { Inappropriate Sandy } \\
\text { soil management }\end{array}$ & 5 & $\begin{array}{l}\text { Inappropriate } \\
\text { planting methods }\end{array}$ & 6 & $\begin{array}{l}\text { Incidence of Early } \\
\text { Shoot borer }\end{array}$ \\
\hline 7 & $\begin{array}{l}\text { Incidence of Red rot } \\
\text { disease }\end{array}$ & 8 & Rat menace & 9 & $\begin{array}{l}\text { Non-adoption of } \\
\text { harvesting at ground } \\
\text { level }\end{array}$ \\
\hline 10 & Heavy Lodging & 11 & $\begin{array}{l}\text { Heavy incidence of } \\
\text { Flowering }\end{array}$ & 12 & Problem soil \\
\hline 13 & Soil test not done & 14 & $\begin{array}{l}\text { Water sample not } \\
\text { tested }\end{array}$ & 15 & $\begin{array}{l}\text { Inappropriate } \\
\text { fertiliser } \\
\text { management }\end{array}$ \\
\hline 16 & $\begin{array}{l}\text { Non-adoption of } \\
\text { basal dressing of } \\
\text { fertiliser }\end{array}$ & 17 & $\begin{array}{l}\text { Inappropriate water } \\
\text { management }\end{array}$ & 18 & $\begin{array}{l}\text { Inadequate land } \\
\text { preparation }\end{array}$ \\
\hline
\end{tabular}


identified: (i) Selection of Sugarcane varieties suitable to upland condition and (ii) Sandy soil Management.

\section{Farmer Experimentation}

It was decided by all the stakeholders to organise ten experiments accordingly in the three villages (Table 4). Then, volunteering farmers who would organise these experiments in their holding were finalised in the presence of the villagers in the meeting.

\section{The results of the ten experiments are given below :}

In Athukkudi village eleven sugarcane varieties suitable to brief drought condition were planted. Excess irrigation

Table 4.

Farmer Experimentation in Selected Villages of Nagappattinam District

\begin{tabular}{|c|l|l|}
\hline $\begin{array}{c}\text { S1. } \\
\text { No. }\end{array}$ & \multicolumn{1}{|c|}{ Village } & \multicolumn{1}{|c|}{ Theme of Experiment } \\
\hline 1 & Athukkudi & $\begin{array}{l}\text { Selection of Sugarcane varieties suitable to brief drought } \\
\text { condition }\end{array}$ \\
\hline 2 & & Methods of Land Preparation \\
\hline 3 & & Water Management \\
\hline 4 & & Management of Early Shoot Borer \\
\hline 5 & & Use of Organic Manure \\
\hline 6 & Thiruvali & Selection of Sugarcane varieties suitable to wetland condition \\
\hline 7 & & Sandy soil Management \\
\hline 8 & & Ratoon Management \\
\hline 9 & Keelaiyur & Selection of Sugarcane varieties suitable to upland condition \\
\hline 10 & & Sandy soil Management \\
\hline
\end{tabular}

was given by the experimenting farmer during the early phase possibly due to over enthusiasm which seriously affected the germination. The experiment had to be discontinued.

The second experiment on methods of land preparation resulted in a yield of $138 \mathrm{t}$ /ha when deep ploughing and formation of ridges and furrows with controlled irrigation compared to formation of ridges and furrows yielding 118.50 tons/ha while the local practice yielded 95.90 tons/ha. The farmers decided to go for formation of ridges and furrows. 
The third experiment on water management did not take off as the identified farmer was hesitant.

The fourth experiment was for managing early shoot bearer. The experimenting farmer ignored cultural and IPM and went for chemical control vitiating the experiment.

The fifth experiment was on trying different choices of use of organic manures and the farmers decided to try trash compost, which was one of the choices.

In Thiruvali village, fourteen varieties were tried for identifying the varieties suitable for wetland situation. The farmers identified three varieties namely, CoG93076,Co 8021 and Co 86010 and decided to go on a commercial scale and also make their village "red rot free".

For sandy soil management, the farmers decided to accept the application of additional dose of nitrogen (25\%) along with local practice.

In the experiment on ratoon management, the farmers preferred ITK (Indigenous Technical Knowledge) of uprooting the sprouts from a corner of the field plant those in the gaps in the remaining field.

In Keelaiyur village, the farmer who agreed to take up the experiment on selection of varieties suitable for upland condition did not try the eleven varieties offered.
In the experiment on Sandy Soil management, the farmers decided to go in for application of additional dose of nitrogen $(25 \%)$ along with local practice.

The experimenting villages were visited again twice with a gap of ten years (2005 and 2015) and interacted with a sample thirty farmers. The impact of the participatory approach was satisfactory. The technologies like formation of ridges and furrows, use of trash compost, Sandy soil management and ratoon management trickled down well in the system. The study area had some of the new varieties tried and free from red rot.

The Participatory Rural Appraisal Methods like Transect Walk had empowered the farmers to participate in the Technology Development and Transfer Process. As the perception of farmers and that of Scientists and Development workers differed widely (Elangovan and Vasanthakumar,1997), the farmers were considered passive users of the technology. Some of the technologies with higher returns were rejected while the ones that are compatible with the existing practices were adopted easily. The technologies adopted, thus get systematised to be part of the farmers' technologies (Ramasubramaniyan, et.al., 2016). The technologies accepted by the farmers through PTD get transferred rapidly among farmers. Further, the study reveals that such technologies remain in the field for a longer time. 
The Transect Analysis, a Participatory Appraisal Method, emerged as a useful tool in identifying the constraints and in evolving a suitable Action Plan to tackle the constraints. However, the priorities of the farmers differed from that of development workers who believed that adequate varieties have been presented. The farmers had a System Perspective while the Scientists had a narrow perspective due to specialisation. The transfer of technology especially the varieties suitable to local condition was rapid whereas the transfer of technology relating to land preparation and use of organic manures was far below the expectation. Thus the Participatory Technology Development and transfer is an important technique in identifying location specific technologies.

\section{REFERENCES}

Arulraj, A. \& Vasanthakumar, J. (1996). Participatory Technology DevelopmentA Case Study, Discussion Paper, 96/11, Sugarcane Breeding Institute,ICAR, Coimbatore, pp.24.

Chambers,R., Pacey, A \& Thrupp, LA (eds.)(1989). Farmer First - Farmer innovation and Agricultural Research, Intermediate Technology Publications, London.
Dhamodaran, T. \& Vasanthakumar, J (1997), Yield Gap and Constraints to High Yields in Sugarcane, Journal of Extension Education, 8(4)

Elangovan, R. \& Vasanthakumar, J (1997). Perception of Extension Officials Towards Eco- friendly Technologies. Tamil Nadu Journal of Extension Education, 8 (3): 17551758.

Garforth, C. \& Harford, N. (1995). Issues in Agricultural ExtensionExperiences of Agriculture and Natural Resource Management Programmes through the 1980s and1990s, AERDD Working Paper 95/6,The University of Reading,UK.

Pretty, J.N .(1995), Regenerating agriculture : an alternative strategy for growth, Earth Scan, London.1825-1828.

Ramasubramaniyan, R., Vasanthakumar, J. \& B.S.Hansra, (2016). Knowledge and Adoption of Conservation Agriculture Technologies by the Farming Community in Different AgroClimatic Zones of Tamil Nadu State in India, Journal of Agricultural Science, 8(11):154-169 